\title{
The Science and Technology Centre "Energy" in Karlino - the project of a new geotourist attraction in Western Pomerania
}

\author{
Zbigniew Gląbiński \\ University of Szczecin, Faculty of Geosciences, ul. Mickiewicza 16, 70-383 Szczecin; \\ e-mail: zbyszek@globtour.pl
}

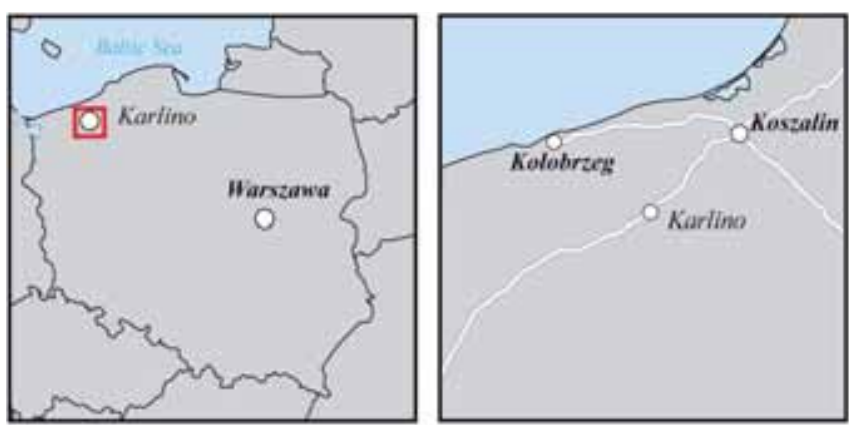

Abstract: Western Pomerania is a region that is known among tourists mainly because of the sandy beaches of the Baltic Sea. Most of the more than 2 million tourists, who visit the region each year, come in summer and head straight for the beach resorts. This leads to a significant space-time concentration of tourism activity, which is not a favourable development in terms of the preservation of natural assets or for socio-economic reasons. The region is perceived as not attractive for cognitive tourism, including geotourism. The eruption of oil and gas in Karlino in 1980 belongs to one of the most interesting events in the recent history of the region. This event has inspired the Karlino municipal authorities to appoint a modern educational museum to commemorate the event and to creatively present the formation processes of energy fuels throughout the geological history of the Earth. The creation of this facility would be an excellent opportunity to popularize geological knowledge among numerous tourists visiting the nearby beach resorts and would also contribute to the socio-economic activation of the residents of the Karlino municipality.

Key words: geotourism, Western Pomerania

\section{Introduction}

Geotourism, which has gathered increasing interest among tourists, is referred to as a form of cognitive tourism, which, with appropriate management, aims to provide tourists with both intelligible information about geological objects and processes, as well as with aesthetic experiences (Słomka, Kicińska-Świderska, 2004; Osadczuk, Osadczuk, 2008; Migoń, 2012 Głąbiński 2014). Undoubtedly, that which constitutes a major problem is coming up with a good way to share the achievements of modern knowledge in the field of geoscience with the widest part of society, while making it comprehensible. Migoń (2012) points out that, what distinguishes geotourism from the earlier forms of cognitive tourism, is its accessible way of providing information, which keeps the substantive correctness, affects the imagination and contributes to a better understanding of the phenomena and natural processes.
In the Polish Lowland areas, the above-mentioned problem is particularly important for several reasons. Firstly, the geotourist attractiveness of that part of Poland is considerably less known than the other areas of mountains and highlands. Moreover, the geological places or geosites located within the Quaternary formations change rapidly or are destroyed by natural or anthropogenic processes. Therefore, the literature on geotourist objects in these areas, as well as the proposals to make them available to a wider group of tourists is scarce (Ber, 1981; Borówka et al., 2008; Cedro, 2005; Dobracki, Walczak-Sy, 2006; Głąbiński, 2009; Kostrzewski et al., 1994; Słomka et al., 2006).

Western Pomerania is a region which is characterised by a particular need to popularize its geotouristic values. The Catalog of Geotourist Objects in Poland mentions only 3 objects in this area (Emerald Lake in Szczecin and two sections of the cliff shores of the Baltic Sea) (Słomka et al., 2006). This does not mean, however, that this region is void of such values, but rather, that they have never been adequately popularized and do not exist in the minds of the residents or tourists (Głąbiński, 2008; 2014). What should be noted, is the fact that the Mecklenburg Lake District in Germany, that Poland shares a border with on the west, represents a similar genesis of landscape, and has had its Geopark and the Ice Age Trail since as early as 2002 (Buddenbohm et al., 2003).

Another argument for the proper promotion and visibility of tourist attractions in the region is the fact that they can have a positive impact on the development of the territorial identity of its population (Głąbiński, 2008; Zaręba, 2006). Due to the diversity of the territorial origins of the Western Pomeranian residents, it turns out to be more the space and landscape factors that influence the formation of a stronger sense of community, rather than other socio-cultural ones (Rybarska-Jarosz, Barylski, 2012). The reasons are due to the diversity of the territorial origin of its resident as well as, various cultural roots of its inhabitants that result from the processes of forced or natural migration.

Although decades have passed since 1980, developing a new territorial awareness in the area of Western Pomerania is still not a completed process. As the researcher has shown, local communities living in the contemporary West Pomeranian Province are not the followers of traditions and customs brought from the regions of their origins (Rydz, 1980; Sakson, 1996; Białecki, 2006). Therefore, the increasing number of people born here, who consider their place of birth as their "homeland", is particularly significant. The surrounding reality, perceived not only in the spatial dimension, but also in terms of the history of the last few years, is something natural for them. As the researchers emphasise, 
their identity is based on both historical memory and the material traces associated with it (Kruczek et al., 2003). For this reason, what is of particular importance to the identity of West Pomeranian inhabitants, includes both the popular facts of recent history that operate in the collective consciousness, as well as the qualities of their natural environment. Thus, any actions taken for their commemoration and promotion will contribute to integrating the community across the region.
The fact that Western Pomerania is one of the most frequently visited tourist regions in Poland constitutes yet another argument for the above-mentioned actions. In 2013, the region was visited by over 2 million tourists (CSO, 2014). Previous studies confirm that a summer holiday by the sea is the tourists' main motive to arrive in the area of Western Pomerania. Other touristically attractive areas are much less frequently visited (Matczak, Rydz, 2001; Szwichtenberg, 2002; 2006).
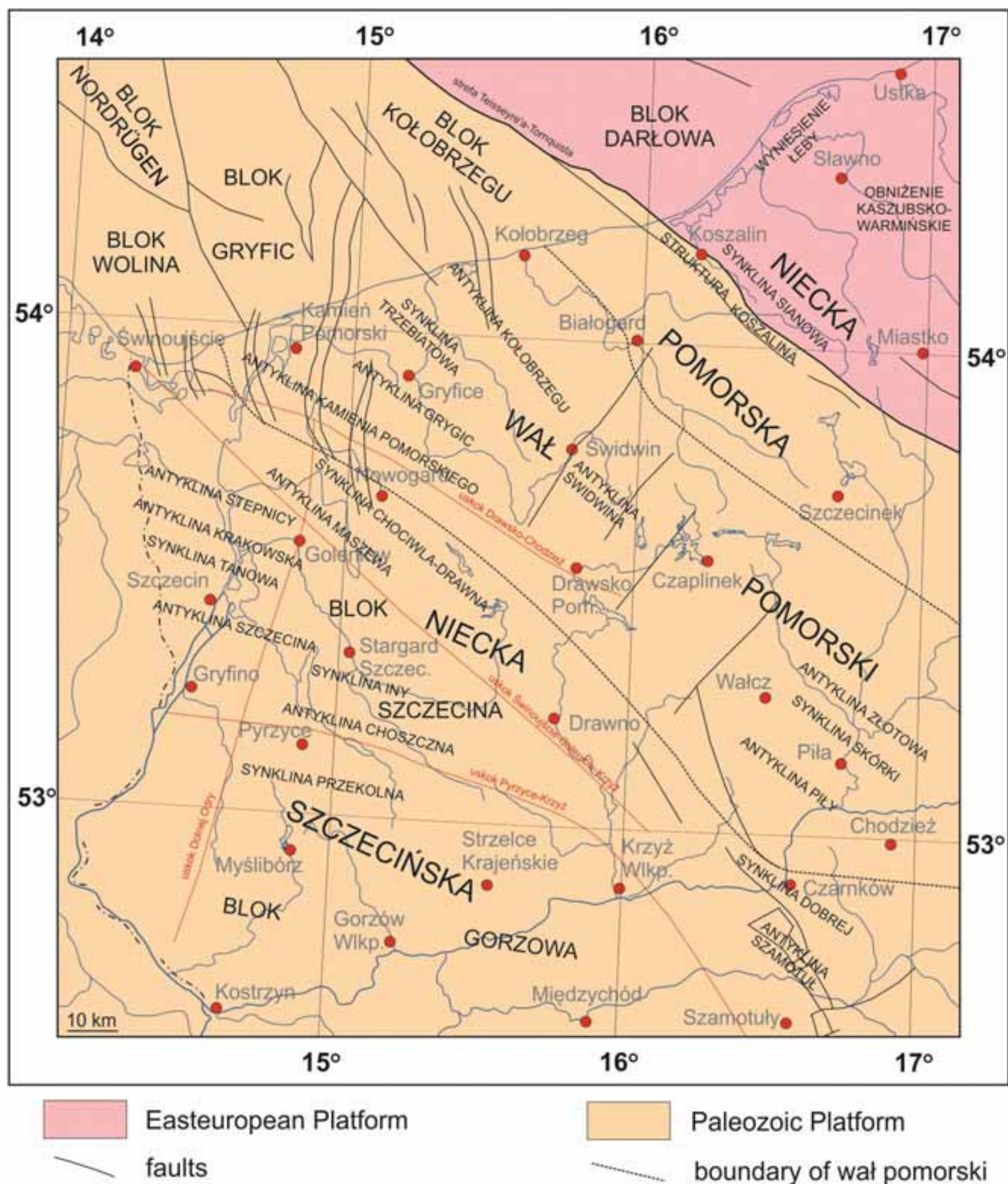

Paleozoic Platform

boundary of wał pomorski

Fig. 1. Geology of Western Pomerania (source: Dadlez, 1995; Dadlez et al., 2000; Pożaryski, Dembowski, 1984) 
Therefore, the problem is to deal with the phenomenon of seasonal and spatial concentration of tourism activity. This is highly negative in terms of the economy, society and natural habitat of the region. The efforts to limit this phenomenon in the region are characterised by a model of tourist arrival " $3 \times$ S" (Sea, Sun, Sand) and revolve around the reorientation and transformation of the traditional perception of such areas (Fernandez-Morales, 2003). The factors that could support these processes involve, among others, the proper management of the targeted area of tourism, seeking to use various tourist assets and, in addition, good promotion of the regional tourist products. Attempts should be made for spatial deconcentration, through the development of infrastructure in such places that have, so far, been of little interest for tourists.

Referring to the foregoing facts and ideas for sustainable tourism based on the " $3 \times$ E" (Entertainment, Exiting, Education) model of assumptions, it is clear that there are good reasons for the development of cognitive tourism in Western Pomerania. What should also be noted is the fact that a better use of the environmental values can significantly alter the perception of the region of Western Pomerania as an attractive tourist destination not only in summer - due to its beautiful beaches, but also throughout the year - in terms of its cognitive aspects.

\section{The eruption of crude oil in Karlino in 1980 and the idea of using this event as a geotourist attraction}

What may be of a particular geotouristic interest are former and contemporary mining facilities (Migoń, 2012). In many places, these mines allow tourists to observe bedrock outcrops in a significantly better degree than in their natural conditions. On the other hand, these mines represent the relationship existing between man and the Earth's natural resources.

The issue of both the relevance and feasibility of the use of tourist values of the mining heritage facilities is quite broadly described in the literature (Pawlikowski et al., 2009; Bartuś, Kuś, 2010; Hvizdak, Hvizdakova, 2011; Rybar, 2011, Schwarz, Lorenc, 2011). The researchers emphasise the social and economic conditions related to providing tourism within such facilities. Certain benefits can result in the growth of the area's tourist attractiveness, the residents' sense of identity and pride in their own region, as well as better environmental conditions and quality of life. Moreover, the mining facilities can have considerable educational impact on children and young people, as well as the whole of society. On the other hand, the mines require substantial investment in order to be opened to the public and to continue functioning.

The places that are associated with borehole mining, primarily relating to oil and natural gas, are a special type of mining facilities. They include the world's oldest mines in the area of Krosno and Gorlice in Poland, as well as Borysław in Ukraine - famous for its long history of the exploitation of these raw materials (Radwański, 2009, 2009a). One of them was made accessible in the form of "The Heritage Museum Museum of Crude Oil and Gas Industry" in Bóbrka.

Karlino, near Białogard in Western Pomerania, constitutes a slightly different case. Two km east of the town, "Daszewo-1", a former hole explored for oil, is located. It has a special place on the map of Poland, resulting from the eruption of crude oil in December 1980, on an unprecedented scale (Karnkowski et al., 1981).

Exploration for crude oil and natural gas on a larger scale has been carried out in Pomerania since 1965 (Karwowski, 1985. Karnkowski et. al., 1981). The Lower Carboniferous and Permian sediments in the Pomeranian Wall and Szczecin Depression were considered to be particularly promising. The first gas field was discovered in the Polish Lowland Carboniferous formations of Wierzchowo nearby Szczecinek as early as in 1971 (Karnowski, 1993) (Fig. 1).

As Dadlez (1980) indicates, in terms of the Pomeranian Anticlinorium regional division, the Karlino areas are located in the Kolobrzeg block, which is characterised by, reduced development of Zechstein deposits. Further research led to the conclusion that, when it comes to the Permian sediments, natural gas occurs in Rotliegend and Zechstein limestone, whereas crude oil together with natural gas can be found in the Main Dolomite and Platy Dolomite (Fig. 2).

\section{Stratigraphic chart with main level deposits of crude oil and natural gas in Poland}

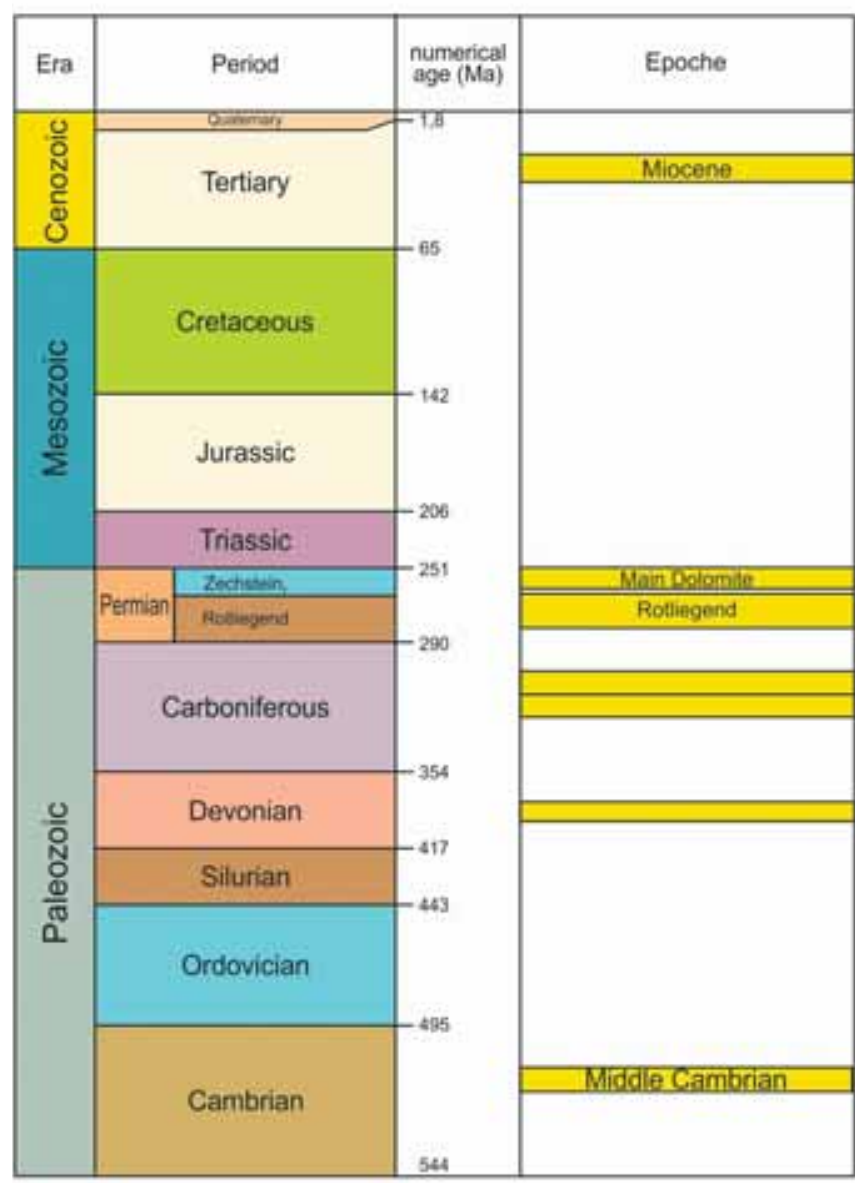

Fig. 2. Stratigraphic chart 


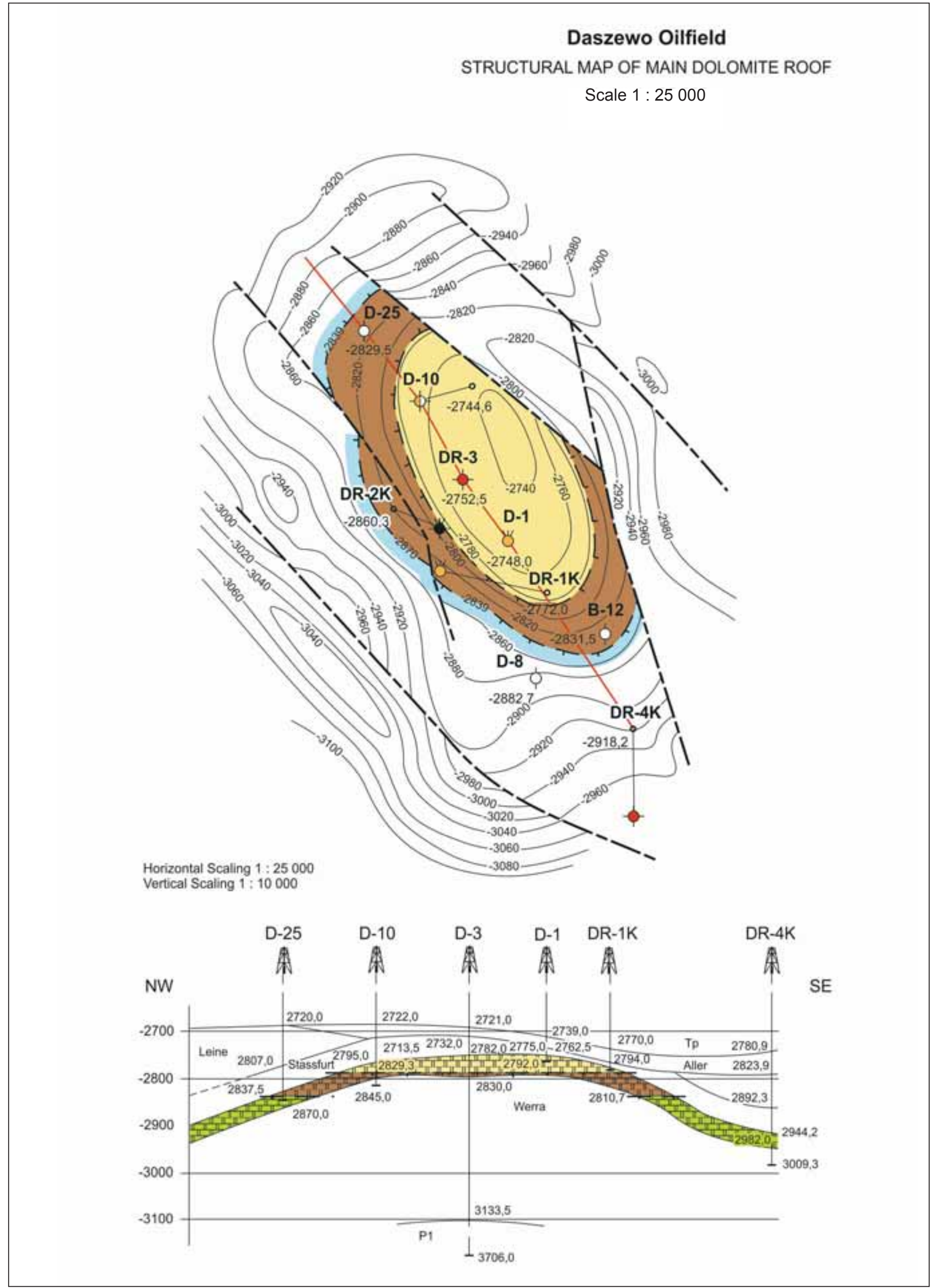

Fig. 3. Daszewo oil field (source: Nowak 2006) 
Deep drilling of Biesiekierz-1 (3111 m) and Karlino-1 $(4322,5 \mathrm{~m})$, carried out in the area of Karlino, and provided more detailed information on the geology of this part of Pomerania. It was demonstrated that the sandstones of the Lower Carboniferous (average porosity of 13.3\%) have better reservoir properties than the Zechstein deposits (average porosity of $1.64 \%$ ) (Karnkowski et. al., 1981). Subsequent studies confirmed that the Main Dolomite constitutes the reservoir of porosity-cavernous-crevasse type. Numerous cracks in in this reservoir are conducive to its permeability and contribute to the fact that the initial extraction of oil from the wells can reach several hundreds of tons per day (Raczyńska, 1987).

Drilling in Daszewo-1 was launched on 12th September, 1980 and aimed to reach the depth of $4100 \mathrm{~m}$. Its objective was to find further reserves of natural gas in the sediments of the Lower Carboniferous (as was the case in Wierzchowo nearby Szczecinek). An additional objective to build the well was to examine the Main Dolomite and Rotliegend rocks, with particular attention paid to the occurrence of bitumen. The analysis of the drilling sections of Biesiekierz-1 and Karlino-1, as well as of the other ones previously performed in Pomerania, pointed out that the roof of Zechstein would be separated by over $100 \mathrm{~m}$ from the Main Dolomite roof. As such, it would occur at the depth of approx. $2850 \mathrm{~m}$, at the shallowest (Karnkowski et. al., 1981). Surprisingly, having reached the depth of $2779 \mathrm{~m}$ on 9th December, the crew drilled into the drift roof of the Main Dolomite deposits containing oil and gas deposits with very high pressure (Fig. 3). At approximately 5.30 p.m., due to the leakage of protection devices, a rapid flow of crude oil and natural gas occurred.

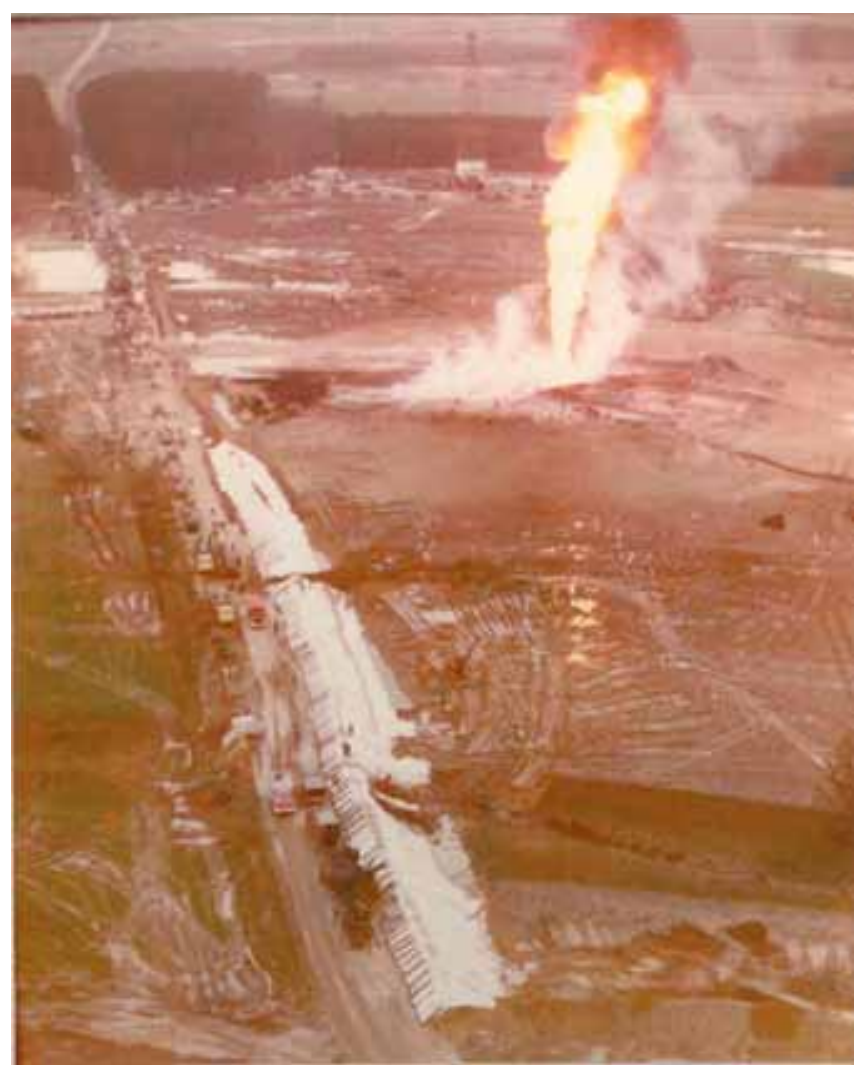

Fig. 4. General view Karlino December 1980 (source: archive of PGNIG SA in Zielona Góra)
It reached the height of the drilling tower (42 m), and, a moment later, underwent autoignition (Karnkowski et al. 1981; Kunert, Habrat, 1981; Macunda, Dubiel, 2010). The fire caused the destruction of the drilling equipment, technical facilities and two farms in the vicinity of the hole (Figs 4, 5, 6 and 7).

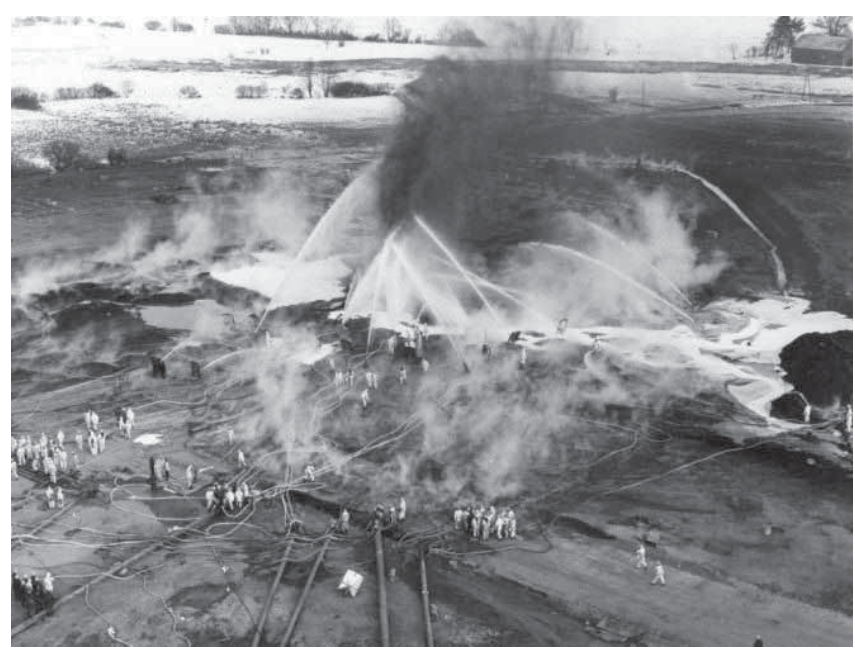

Fig. 5. Fire fighting (source: Karlino Commune Office)

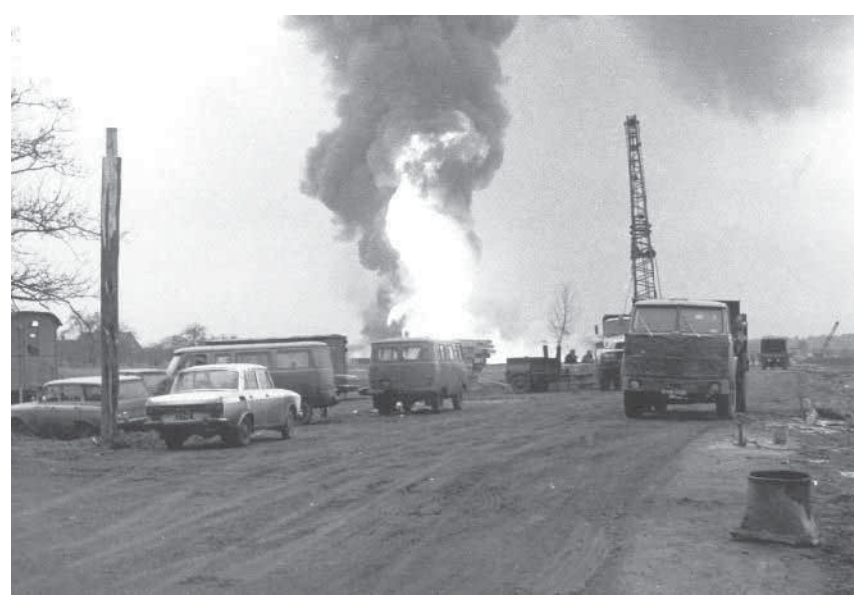

Fig. 6. Fire of oil rig December 1980 (source: Karlino Commune Office)

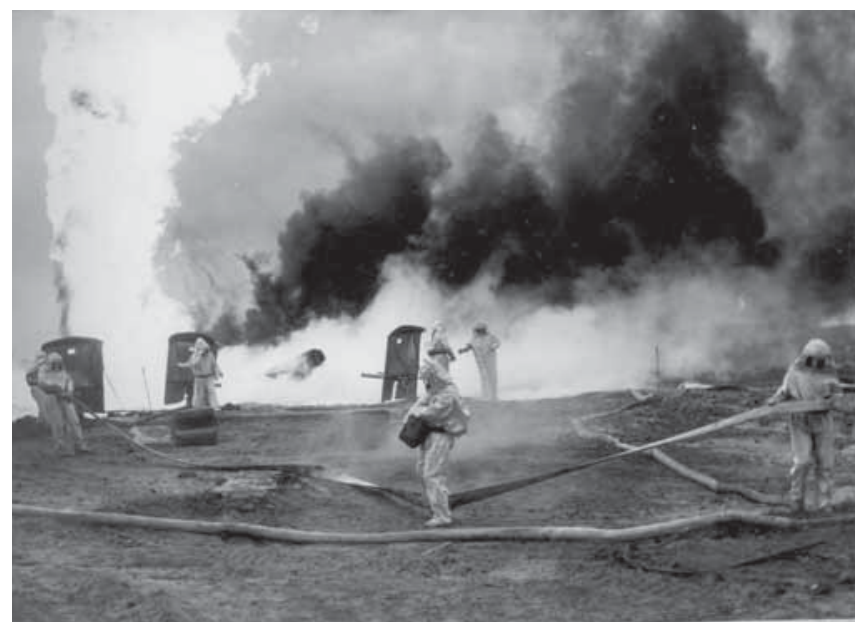

Fig. 7. Rescue action December 1980 (source: Karlino Commune Office) 
The rescue operation began the next day to liquidate the eruption. In the meantime, the media information about the outbreak of oil and gas in Karlino in Pomerania triggered a wave of sensational speculations. Karlino became famous in the whole country and was dubbed the "Polish Kuwait".

One of the most difficult tasks of the rescue operation included the removal of the damaged blowout preventer. Over 200 bullets from various pieces of artillery were shot. Finally, the preventer was removed by a $152 \mathrm{~mm}$ howitzer on 28th December. In addition, the decision was taken to make emergency drillings in DR-1k and DR-2k (Fig. 3). These wells were later used in the exploitation of the deposit.

The fire-fighting operation, which was attended by the employees of the Polish Oil and Gas Exploration Company, the Fire Brigade, the Militia, the Polish Army, specialists from AGH University of Science and Technology in Cracow and advisers from Hungary and the Soviet Union, lasted for over a month and was finally completed on 14th January 1981. It was the largest rescue operation associated with the eruption of crude oil and a well fire in Poland and, according to contemporary opinions, also one of the largest ones in the world (Kunert, Habrat, 1981).

It was not long after the completion of the rescue operation (as early as 16th January 1981) when the commissioning of the exploitation installation was initiated and the first oil was transported with tankers from the Karlino station to the refinery in Trzebinia. Later, the unlucky D-1 hole was filled with drilling fluid, and remained exploited until 1983 via the automatic outflow of oil from the DR-1k well (Fig. 3).

After the cessation of the spontaneous outflow, a decision was made to rebuild reservoir pressure by injecting gas from the deposits of Białogard, distant by a few kilometres (Nowak, 2006). Further operations in the DR-1k well were active up until 2005. In total, the Daszewo deposits provided :

- 248.2 thousand tons of crude oil,

- 113.2 million $\mathrm{m} 3$ of natural gas.

Since 2009, the D-1 and DR-1k holes have been used in the operations of the Daszewo Underground Gas Storage facility, which has a capacity of $30 \mathrm{mln} 3$ (PGNiG Zielona Gora; Macunda, Dubiel, 2010). One should note that, when currently driving on the No. 6 National Road, the only thing that can be seen on the site of the famous events of 1980 and 1981 , is the USG "Daszewo" installation. No other landscape elements commemorate those dramatic events. Moreover, there has been no evidence of the impact of the eruption and fire of oil on the soil and aquatic environment around the D-1 hole (Macunda, Dubiel, 2010).

\section{The justification for the creation of the Science and Technology Centre "Energy" in Karlino}

The news that was transmitted in the media, during the rescue operation was subject to censorship, due to the prevailing socio-political system in Poland. This made the Polish society disbelieve in the information flowing from Karlino.
The foregoing fact, as well as the presence of the specialist rescuers, who arrived at the place from the former Soviet Union, contributed to the aura of mystery that arose around the event. In people's everyday consciousness, the oil and gas deposit in Karlino became a part of a large, underground reservoir stretching from the Baltic Sea to the Persian Gulf. In the awareness of Polish people, exploitation of the deposit, was associated with political circumstances that, at that time, resulted from Polish dependence on the Soviet Union. This fact became so deeply engrained in the memory of many Polish people, that they still associate the name of Karlino with the events recounted by contemporary media.

Currently, tourists travelling on holidays to the Baltic Sea often pass through Karlino, located at the intersection of National Road No. 6 (Szczecin - Gdańsk) and the Provincial Road No. 163 (Wałcz - Kolobrzeg). Few of them, however, stop when heading north-west to Kolobrzeg, about $28 \mathrm{~km}$ away. This most likely is the result of the fact that Karlino is perceived as a touristically unsightly town. This view is confirmed by Milewski (2002) who, by means of a taxonomic measure of development, analysed the attractiveness of the region. His classification put Karlino only in the $64^{\text {th }}$ place among 114 municipalities of the West Pomeranian Province.

Nowadays, the authorities and residents of local communities in Poland see some opportunities for local development by increasing the number of incoming tourists, by either promoting the existing tourism products by creating entirely new ones. The authorities of some towns, associations or other private entrepreneurs have taken various actions to gain the interest of tourists in their regional attractions. Examples of such places promoted include: the Centre for Education and Regional Promotion in Szymbark in Kaszuby, the Heritage Park of the Slavs and Vikings in Wolin or the Jurassic Park in Bałtowo, which are all visited by thousands of tourists every year.

Creating new geotourist attractions, particularly those related to the old mining buildings, however, often requires large investments (Schwarz, Lorenc, 2011). It is easier to undertake such projects in those areas which, due to the presence of the natural geological values, are predestined to create geotourist attraction, such as., the mountains and upland areas.

Despite the above-mentioned obstacles, the district authorities of Karlino have been taking some action for several years to take advantage of the historical event of the largest oil and gas eruption in Poland. This event might support in the creation of a new geotourist attraction on a regional, and eventually national, scale. Such efforts are consistent with the opinion of Migon (2012), who claims that the initiative to offer geotouristic attractions may arise from the interest of the scientific community from the local level (government municipalities, local action groups).

As far as Karlino is concerned, we are dealing with a fairly specific situation, as the former mine is used by the Underground Gas Storage "Daszewo". Therefore, it is not possible to turn this space into a tourist attraction because it is an object that remains in current operation.

As such, the municipal authorities are planning to build a geotourist facility near the spot, where all the events associated with the eruption of oil and gas from the Daszewo-1 oil well occurred at the end of 1980 and the start of 1981. This is 
an interesting solution to the dilemma of both the theoretical and practical nature. According to Migoń (2012 p. 53), an event that is accessible to tourists, also in relation to geotourism, may have tourist value. Undoubtedly, the eruption of oil and gas in Karlino in 1980 was such an event. Due to the fact that it is impossible to explore the former mine, which is the place of current operations, the municipal authorities decided to build a facility, in which it will be possible to reconstruct the course of the eruption and the well fire. It is to be located in less than $2 \mathrm{~km}$ from the original place.

The project of the Science and Technology Centre "Energy" came into being a few years ago. The "Museum of the Earth - on the border between worlds" exhibition is to be opened there. The facility is going to be built on a lot nearby the intersection of the National Road No. 6 in the direction of Gdańsk and the Provincial Road No. 163 in the direction of Kołobrzeg. The proposed project will consist of a field exhibition and a largesize structure referring to the Giant Causeway located in County Antrim in Northern Ireland (Figs 8, 9). The project that won the competition announced by the municipal authorities clearly refers to one of the world's "geotourist icons" in this way. It is clear that the initiators of this idea are guided by the same principle. This will be the first facility of its kind in Poland, whose architecture will highlight its typically geotouristic character.

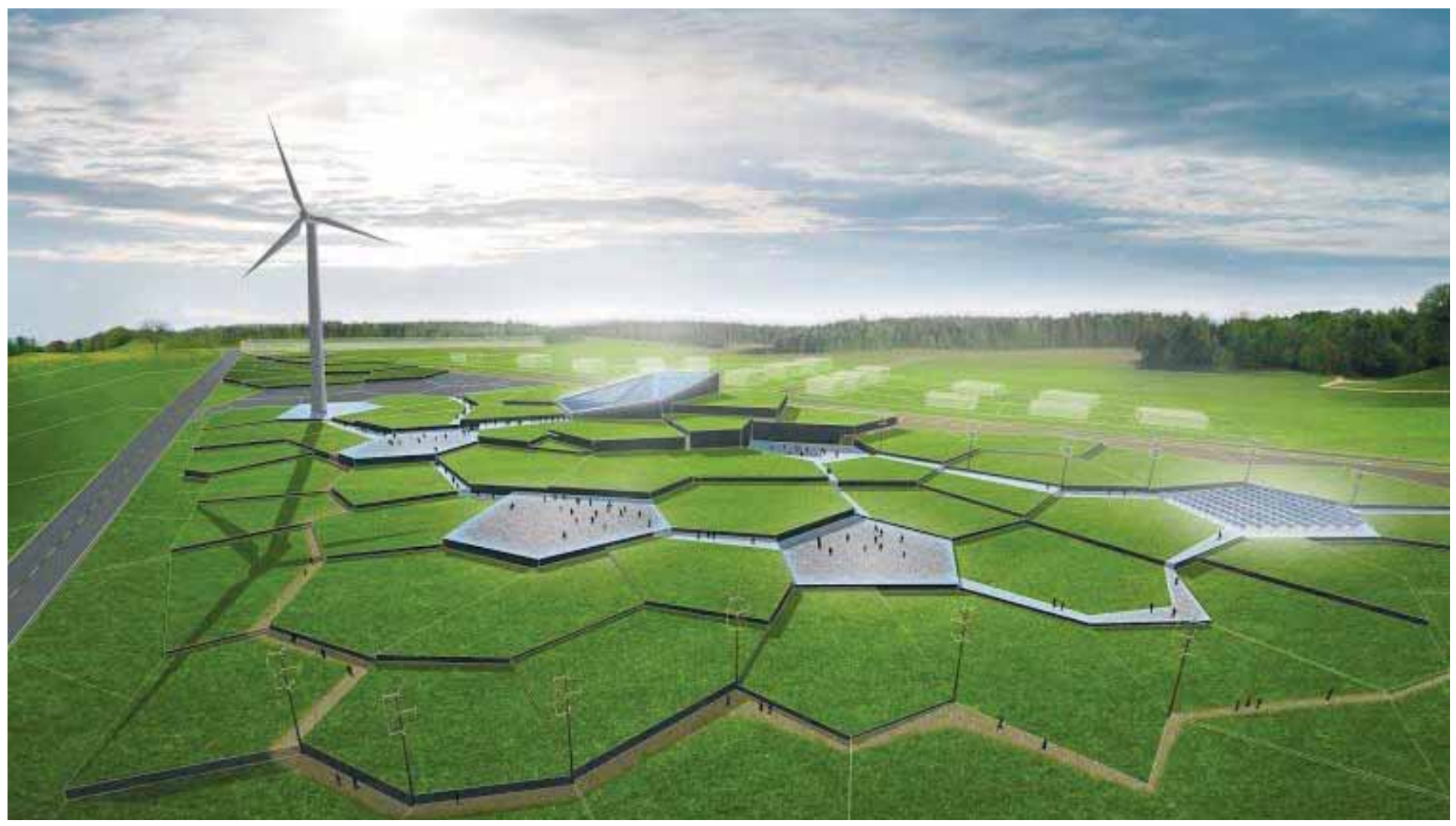

Fig. 8. The Science and Technology Center - general view (source: Karlino Commune Office)

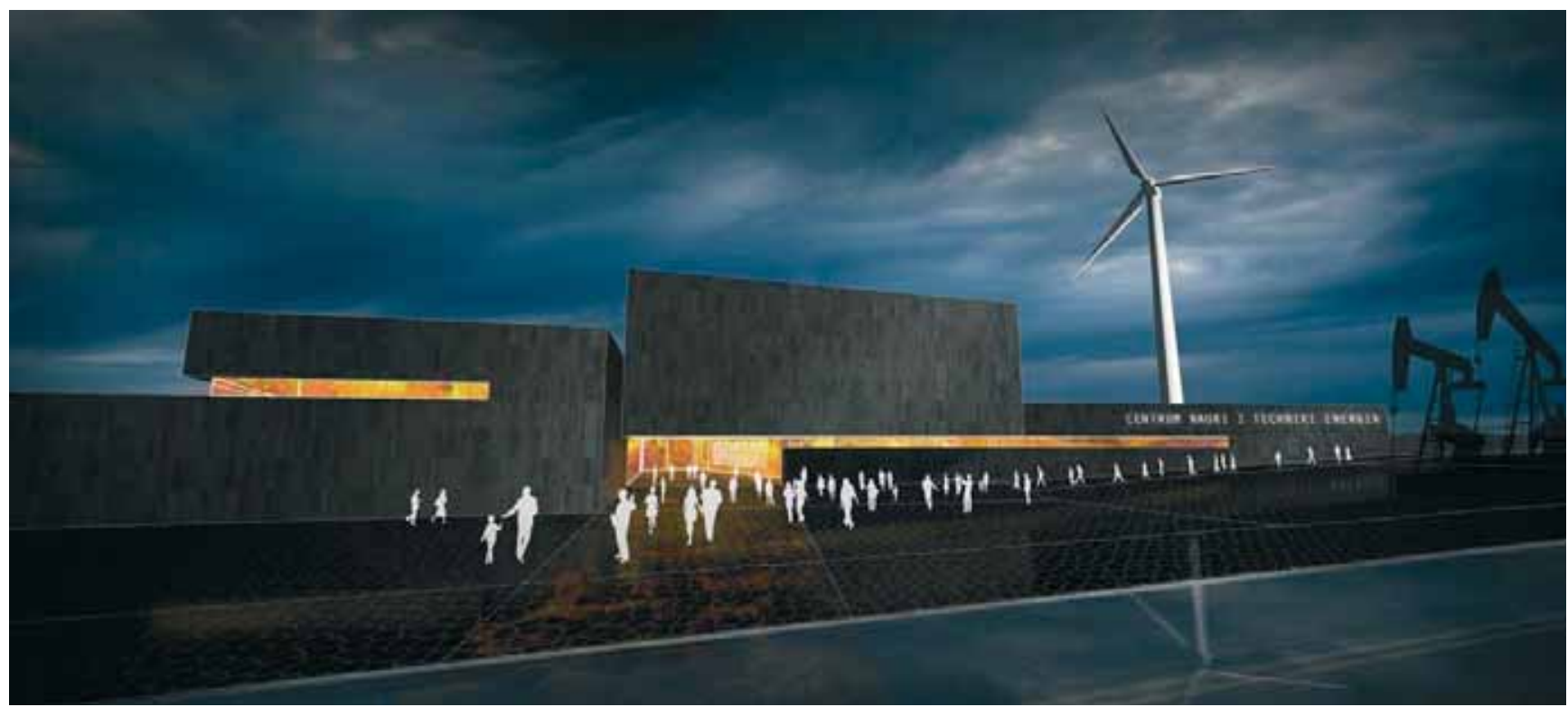

Fig. 9 . The Science and Technology Center - main entrance (source: Karlino Commune Office) 
What constitutes a major problem faced by the initiators of the construction is the necessity to overcome the barrier of people's disbelief in the usefulness of the site for presenting the history of the Earth. Undoubtedly, little varied landform of Białogard Plains, within which Karlino is located, as well as its unattractive unveilings resulting from the aggregate operations in this part of Poland, do not excite the imagination of potential tourists in geological processes. In this situation, the most important issue is to work on the project in such a way that, by preparing an interesting, interactive exhibition, proper interpretation and transmission of frequently difficult issues related to the Earth's heritage, the cognitive interests of tourists arriving at the Baltic coast would be raised.

This issue is quite broadly reflected in literature, especially in relation to tourism in the protected areas (Ballatyne, Packer, 2005; Budeanu, 2007; Duim, Caalders, 2002; Głąbiński 2015, Orams, 1995; 1997; Zaręba, 2006). The case of Karlino is justified because the neighbouring coastal areas constitute the Natura 2000 site (Trzebiatów-Kołobrzeg Sea Band PLH320017, Pomeranian Bay PLB 990003). The researchers point out that by educating those visiting environmentally valuable areas, one can contribute a positive change of their attitudes and behaviour towards nature. It is desirable to create a facility that would take into account the educational aspects related to cognitive tourism connected with nature, which geotourism is a part of. Migoń's definition of geotourism (2012) can justify the opinion: "Geotourism, understood as a form of tourism, which is to inform tourists and provide such facilities that, when visiting interesting places, in addition to purely aesthetic experience, they would also be able to assimilate the knowledge needed to understand geology and geomorphology of the visited area". The designed facility is assumed to positively affect the awareness of numerous tourists who, visiting the adjacent coastal areas, will incidentally gain some knowledge in the field of earth sciences. This creates a great opportunity to promote the idea of geotourism. It stems from the fact that in 2013, 3, 860,000 overnight stays were recorded in the neighbouring county of Kołobrzeg, the highest rank in Poland (Central Office of Statistics 2014). As such the number of those who could potentially visit the Centre is significant.

\section{The initial assumptions for planned exhibitions and organisation of sightseeing}

Since the idea of the Science and Technology Centre "Energy" is currently at the stage of technical and economic preparations, coupled with fundraising, no detailed exhibition plan has yet been created. It has only been agreed was that the plan will cover:

- the geological issues describing the chronological history of the Earth,

- presentations of the processes of the creation of fossil fuels in different geological eras,

- energy properties, and the history of exploitation by man.

\section{The audiovisual room}

The room will be used during fictionalised outdoor performances illustrating the eruption of crude oil and gas, as well as the Daszewo-1 well fire in December 1980. It is also going to be a place for all sorts of theatrical, multimedia or IMAX shows.

\section{The inner courtyard}

The courtyard will be surrounded by complex segments, where it will be possible to watch the spectacle of the eruption and Daszewo-1 fire from the inside of the audiovisual room. One wall will be glazed for this purpose.

\section{The accessibility of the exhibition (individual travellers, families, school groups)}

The building should be adapted to utilise and adapt to changing needs in the future. The exhibition is anticipated to be adjusted to:

- permanent and temporary exhibitions (recurring),

- independent tours of individual tourists,

- guided tours,

- educational activities for school groups.

In addition, the facility operation should provide for active forms of promotion and broader education in earth sciences? Supporting materials include:

- educational (printed materials, samples of minerals and rocks, fossils, models, experimentarium),

- interactive website (presentation and promotion of the museum, ticket booking on-line, materials to be downloaded before coming to the museum),

- a newsletter for visitors,

- a shop for visitors.

Various cyclical events as well as educational and popular scientific events (St. Barbara's Day, Earth Day, Clean Up the World and others) should also be organised in the complex.

\section{The significance and functions of the designed facility}

The Science and Technology Centre "Energy" that is being designed will play a serious economic role for the inhabitants of the Karlino municipality. As the research shows, the ratio of residents to tourists often depends on the personal profits received in connection with the development of tourism (Andereck, Nyaupane, 2011). The existence of the Centre will result in the creation of new jobs, related to incoming tourists, not only in the facility itself, but also in providing all supporting services (catering, shopping). In addition to the economic effect, this type of facility should also have a positive impact on the growth of Karlino's inhabitants' sense of identity with their town. With regard to the previous opinions on implementing the objectives of social politics, such a significant investment can completely change the perception of this part of Western Pomerania. This may, within the next stages, contribute to creating a number of new initiatives which would take advantage of the existing qualities of both the natural environment and of cultural heritage. These could involve: 
- the canoe trail on the Parsęta and Radew Rivers;

- the multi-thematic trail from the largest boulder in Europe - Tychowo via Podborsko (POW camp of WWII airmen) - Świelubie - Bardy (one of the largest archaeological sites) to Kołobrzeg;

- the Pomeranian section of the Salt Trail (Poznań - Kołobrzeg).

\section{Conclusions}

Given the circumstances presented above, as well as the assumptions for the Science and Technology Centre "Energy", creating this type of facility is, completely justified. The idea of its development is in line with the trends of global tourism, which primarily involve the attempts to change the trips' formula from relaxation and entertainment to activity, education and knowledge. The unique contemporary history of Karlino makes it ideal for creating a new geotourist attraction, whose future importance cannot be overestimated. Another justification of a strictly geological nature is Karlino's close neighbourhood with the Tornquist-Teisseyre line, which runs only a few kilometres to the east. What's more, the geological structure of the ground surrounding Karlino reflects the strong relationship between the earth and its existence. The fact that this very important boundary of Europe's structural units intersects Poland is obvious for geologists, but is not very popularised in society at large. The nearby Danish island of Bornholm, where this border constituted one of the reasons for the creation of a modern museum and educational centre Natur-Bornholm, is a perfect example of how geotourism can develop. Releasing and presenting the information on this subject would contribute to an increase in the level of geological knowledge among Western Pomerania visitors and locals.

It should be emphasised, that the achievements of Polish geologists, including Roman Teisseyre, could be additionally honoured in this way. Since the Tornquist-Teisseyre line is a very important border of geological structures dividing the whole surface of Europe, it would be advisable to use this fact in the part of the exhibition relating to the history of the Earth. Perhaps, the exhibition could be called the Museum of the Earth - on the border of the worlds. Using this type of terminology is consistent with the previously presented views that complex issues should be presented in a way that raises the interest among tourists (Ballatyne, Packer, 2005; Głąbiński 2008; Orams, 1997).

The municipal authorities see their chance to accomplish the project in obtaining the funds by submitting an application to the Regional Operational Programme Infrastructure and Environment 2014-2020 or to the Interreg VA programme, as well as financing from the National Fund for Environmental Protection and Water Management. Given the current conditions related to the priorities of EU regional policy and the support for the initiative of constructing the Centre from the scientific community (University of Science and Technology in Cracow, Polish Geological Institute, Technical University of Koszalin, University of Szczecin) and the tourism community (The West Chamber of Tourism, The West Regional Tourism Organisation), one should expect this investment to be accomplished.

\section{Acknowledgements}

I would like to thank Mr Waldemar Miśko, Karlino's Mayor, and the Municipal Office employees for all the materials and photographs that were used in the article. I am also thankful to Mrs Justyna Olszewska and Mrs Kamilla Pacek from the Department of Geology and Exploitation of the Polish Oil and Gas Company for making their documentation and drawings on the Daszewo geological oil reserves available. I would like to thank Mr Pawet Sydor from the Polish Geological Institute National Research Institute for the consent to use the geological map of Western Pomerania.

\section{References}

Andereck K., Nyaupane G., 2011. Exploring the Nature of Tourism and Quality of Life Perceptions among Residents. Journal of Travel Research 50: 248-260.

Ballatyne R., Packer J., 2005. Promoting Environmentally Sustainable Attitudes and Behaviour Through Free-choice Learning Experiences: What is State of the Game? Environmental Education Research, 11(3): 281-295.

Bartuś T., Kuś T., 2010. Szlachtowski obszar eksploatacji kruszców, jako element projektowanego geoparku "Pieniny." Geoturystyka, 21: 35-58.

Ber A., 1981. Pojezierze Suwalsko-Augustowskie. Przewodnik geologiczny. Wydawnictwa Geologiczne, Warszawa.

Białecki T., 2006. Tendencje rozwojowe ludności Pomorza Zachodniego po drugiej wojnie światowej. In: Od Polski Ludowej do III RP w Unii Europejskiej. Pomorze Zachodnie 1945-2005. Wydział Humanistyczny USz, PTH Oddział Szczecin.

Borówka R.K., Cedro B., Duda T., Woziński R., 2008. Obiekty geoturystyczne na wyspie Wolin oraz ocena ich przydatności dla potrzeb turystyki edukacyjnej. Problemy Turystyki i Rekreacji, 1: 101-110.

Budeanu A., 2007. Sustainable tourists behaviour - a discussion of opportunities for change. International Journal of Consumer Studies, 31: 499-508.

Buddenbohm A., Granitzki K., Strübing H., Daedlow W., 2003. Auf den Spuren der Eiszeit. Geopark. Meklemburgische Eiszeitlandschaft. Geowissenschaftlischer Verein, Neubrandenburg.
Raczyńska A. (ed.), 1987. Budowa geologiczna wału pomorskiego i jego podłoża. Prace Badawcze Instytutu Geologicznego, T. 119. Wydawnictwa Geologiczne, Warszawa.

Cagaj W., Leśniak T., 2005. Valuation of abiotic nature objects. In: Doktor M., Golonka J. (eds), Geotourism - new dimensions in XXI century tourism and chances for future development. Akademia Górniczo-Hutnicza, Kraków.

Cedro B., 2005. Rozmieszczenie i stan obecny odsłonięć osadów mezozoicznych na Pomorzu Zachodnim. In: Borówka R.K., Musielak S. (eds), Środowisko przyrodnicze wybrzeży Zatoki Pomorskiej i Zalewu Szczecińskiego. Oficyna In Plus, Szczecin.

Dadlez R., 1980. Tektonika wału pomorskiego. Kwartalnik Geologiczny, 24(4): 741-767.

Dadlez R. (ed.), 1995. Atlas geologiczny poludniowego Battyku. Państwowy Instytut Geologiczny, Warszawa.

Dadlez R., Marek S., Pokorski J. (eds), 2000. Mapa geologiczna Polski bez utworów kenozoiku. Państwowy Instytut Geologiczny, Warszawa.

Dobracki R., Walczak-Sy A., 2006. Projektowane geologiczne stanowisko dokumentacyjne przyrody nieożywionej w żwirowni w Storkowie. In: Ochrona przyrody $w$ parkach krajobrazowych, konferencja naukowa, 19-20 września 2006, Barzkowice.

Duim R., Caalders J., 2002. Biodiversity and Tourism. Impact and Intervention. Annals of Tourism Research, 29(3): 743-761. 
Fernandez-Morales A., 2003. Decomposing seasonal concentration. Annals of Tourism Research, 30(4): 942-956.

Głąbiński Z., 2008. Szkolny ruch turystyczno-krajoznawczy jako czynnik ksztaltowania tożsamości regionalnej na przykładzie województwa zachodniopomorskiego. Forum Turystyki Regionów, Szczecin.

Głąbiński Z. (ed.), 2009. Tajemnice krajobrazów Pomorza Zachodniego przewodnik dla dociekliwych. Forum Turystyki Regionów, Szczecin.

Głąbiński Z., 2014. Walory turystyczne nadmorskich obszarów Natura 2000. In: Głąbiński Z. (ed.), Jak organizować turystykę na nadmorskich obszarach Natura 2000. Uniwersytet Szczeciński: 59-69.

Głąbiński Z., 2015. The ecological awareness of tourists in the coastal areas of Poland - preliminary results of the survey. In: Szymańska D. Chodkowska-Miszczuk J. (eds), Bulletin of Geography. Socio-economic Series, 29, Nicolaus Copernicus University, Toruń.

Hvizdak L., Hvizdakova J., 2011. Mining tourism - Gelnica and surroundings. In: Słomka T. (ed), Geotourism. A Variety of Aspects. AGH University of Science and Technology, Kraków.

Karnkowski P., Sikorski B., Solak M., 1981. Nowe złoże ropy naftowej pod Karlinem. Przeglad Geologiczny, 29(5): 218-225.

Karnkowski P., 1993. Złoża gazu ziemnego i ropy naftowej $w$ Polsce. Tom 1 - Niż Polski. Towarzystwo Geosynoptyków GEOS AGH, Kraków.

Karwowski L. 1985. Analiza mikrofacjalna węglanowych utworów cechsztynu w strefie Koszalin- Chojnice. Acta Societatis Geologorum Poloniae, 55/3-4: 423-472.

Kostrzewski A., Dzbanuszek J., Stach A., Szpikowski J.,1994. Dalęcińska morena czolowa - propozycja ochrony krajobrazu. Zlewnia Górnej Parsęty - problem zachowania bio- $i$ georóżnorodności. Zintegrowany monitoring środowiska przyrodniczego. Stacja bazowa Storkowo. Biblioteka Monitoringu Środowiska, Warszawa.

Kruczek Z., Kurek A., Nowacki M., 2003. Krajoznawstwo. Zarys teori i metodyki. Proksenia, Kraków.

Kunert W., Habrat S., 1981. Akcja ratownicza dla opanowania erupcji i pożaru ropy naftowej i gazu ziemnego na wiertni Daszewo-1. Bezpieczeństwo Pracy w Górnictwie, 3: 20-27.

Macunda J., Dubiel S., 2010. Ocena wpływu erupcji ropy naftowej na środowisko gruntowo-wodne na przykładzie otworu Daszewo-1. Wiertnictwo Nafta Gaz, 1-2: 251-259.

Matczak A., Rydz. E. 2001. Koncepcja monitoringu ruchu turystycznego w strefie brzegowej Bałtyku. In: Turystyka jako czynnik rozwoju regionów, miast i obszarów wiejskich. Wyższa Pomorska Szkoła Turystyki i Hotelarstwa w Bydgoszczy, 183-193.

Migoń P., 2012. Geoturystyka. Wydawnictwo Naukowe PWN, Warszawa.

Milewski D., 2005. Regionalne uwarunkowania rozwoju turystyki na przykładzie województwa zachodniopomorskiego. Rozprawy i Studia, 518. Wydawnictwo Naukowe US, Szczecin.

Nowak J., 2006. Dokumentacja geologiczna złoża ropy naftowej Daszewo w kategorii A - dodatek $\mathrm{nr} 4$ - wniosek o przekwalifikowanie zasobów. PGNiG Oddział w Zielonej Górze, Poznań.

Orams M., B., 1995. Using Interpretation to Manage Nature-based Tourism. Journal of Sustainable Tourism, 4(2): 81-94.

Orams M.B., 1997. The Effectiveness of Environmental Education: Can We Turn Tourists into 'Greenies'? Progress in tourism and hospitality research, 3: 295-306.
Osadczuk A., Osadczuk K., 2008. Szanse i perspektywy rozwoju geoturystyki jako nowej formy postrzegania obiektów przyrody nieożywionej i poznawania zjawisk naturalnych. Problemy Turystyki i Rekreacji, 1: 131-142.

Pawlikowski M., Pieprzyk-Klimaszewska K., Mikoś T., 2009. Prakopalnie miedzi obiektami geoturystyczno-archeologicznymi południowego Uralu. Geoturystyka, 16-17: 41-44.

Pożaryski W., Dembowski Z., 1984. Mapa geologiczna Polski i krajów ościennych. Wydawnictwa Geologiczne, Warszawa.

Radwański A., 2009. The oil and ozokerite mine in Boryslav and historical monuments of petroleum and salt industries in the vicinity of Boryslav (Ukrainian Fore-Carpathian region). Geoturystyka, 18: 35-44.

Radwański A., 2009a. The Ignacy Łukasiewicz Memorial Museum of Oil and Gas Industry in Bóbrka and historical monuments of petroleum and salt industries in the vicinity of Krosno (the Polish Outer Carpathians). Geoturystyka, 18: 51-60.

Rybar P., 2011. Implementation and economic aspects of mining heritage tourism in Slovak Republic. In: Słomka T. (ed), Geotourism. A Variety of Aspects. AGH University of Science and Technology, Kraków.

Rybarska-Jarosz D., Barylski L., 2012. Tożsamość regionalna mieszkańców województwa zachodniopomorskiego. Raport z badań eksploracyjno-diagnostycznych. Urząd Marszałkowski Województwa Zachodniopomorskiego.

Rydz E., 1980. Charakterystyka geograficzna Pobrzeża Zachodniopomorskiego. In: Borzycki Z. (ed), Porty morskie i walory rekreacyjno-turystyczne Pobrzeża Zachodniopomorskiego. Krajowa Agencja Wydawnicza, Szczecin.

Sakson A., 1996. Procesy integracji i dezintegracji społecznej na Ziemiach Zachodnich i północnych Polski po 1945 roku. In: Sakson A. (ed.), Pomorze - trudna Ojczyzna? Instytut Zachodni, Poznań.

Schwarz S., Lorenc M., 2011. From mining the landscape to mining wallets: mining heritage tourism in four European regions. In: Słomka T. (ed), Geotourism. A Variety of Aspects. Akademia Górniczo-Hutnicza, Kraków.

Słomka T., Kicińska-Świderska A., Doktor M., Joniec A. (eds), 2006. Katalog obiektów geoturystycznych. Akademia Górniczo-Hutnicza, Kraków.

Szwichtenberg A., 2002. Walory środowiska przyrodniczego - szansą dla rozwoju nowych form turystyki na Pomorzu Zachodnim. In: Borówka R.K., Witkowski A. (eds), Człowiek $i$ środowisko przyrodnicze Pomorza Zachodniego (II Środowisko abiotyczne). Oficyna In Plus, Szczecin.

Szwichtenberg A., 2006. Gospodarka turystyczna polskiego wybrzeża. Wydawnictwo Uczelniane Politechniki Koszalińskiej, Koszalin.

Turystyka w 2013. GUS, Warszawa.

Zaręba D., 2006. Ekoturystyka. Wydawnictwo Naukowe PWN, Warszawa.

\section{Websites}

http://www.pgi.gov.pl/pl/oddzial-pomorski-v/geologia-pomorza-zachodniego/5312-pomorze-zachodnie-pigulka.html 21.10.2014

http://zielonagora.pgnig.pl/documents/29748/961630/PMG+Daszewo.pdf/3e93cf0a-ce4b-4591-9fa2-9717565df8c3 20.10.2014 